\title{
DESIGN RESPONSE SPECTRA BASED ON EARTHQUAKE HAZARD MAPS AND SPECIFIC SOIL PROPERTIES AT INDONESIAN PORTS ACCORDING TO SNI 1726:2019
}

\author{
Christino Boyke Surya Permana ${ }^{[1]}$ \\ ${ }^{[1]}$ Dosen, Departemen Teknik Transportasi Laut, Institut Teknologi Sepuluh Nopember \\ Email: c.boyke@ seatrans.its.ac.id, christino.boyke@gmail.com
}

\begin{abstract}
Indonesia has a new seismic code, namely SNI 1726:2019 (SNI 2019). It is developed based on the 2017 Indonesian Earthquake Source, Hazard Maps, and ASCE 7-16. This paper is intended to explain the procedure for calculating response spectrum according to SNI 1726:2019, at ten ports located in Indonesia. The results are then verified with the software RSA2019. Furthermore, it will be compared to SNI 1726:2012 (SNI 2012) to see the spectral acceleration value difference (Sa). The result presents that the ports located in Sorong and Banggai have the highest $\mathrm{Sa}$, whereas the port in Banjarmasin has the smallest value. Port in Surabaya and Tuban have nearly the same Sa due to their close location, while Banyuwangi has a Sa value slightly above them. The ports in Padang, Lampung, and Penajam must use a specific site response analysis to determine the design response spectra, which is not discussed in this paper. The comparison with SNI 2012 shows that the response spectra of SNI 2019 have a higher Sa than SNI 2012. However, in some areas such as Tuban and Sorong, the Sa of SNI 2012 at 0.1 to 0.6 s period are more significant than SNI 2019.
\end{abstract}

Keywords: response spectra, SNI 1726:2019, port, Indonesia.

\begin{abstract}
ABSTRAK
Indonesia memiliki tata cara perencanaan ketahanan gempa baru yaitu SNI 1726:2019 (SNI 2019). SNI 2019 dikembangkan berdasarkan Peta Sumber dan Bahaya Gempa Indonesia 2017, dan ASCE 7-16. Makalah ini dimaksudkan untuk menjelaskan tata cara penghitungan respons spektrum menurut SNI 1726:2019, dengan contoh perhitungan pada 10 pelabuhan di Indonesia. Hasil perhitungan tersebut kemudian akan diverifikasi dengan perangkat lunak RSA2019. Selain itu, hasil juga akan dibandingkan dengan SNI 1726:2012 (SNI 2012) untuk melihat perbedaan nilai percepatan spektrum ( $\mathrm{Sa}$ ). Hasil penelitian menunjukkan bahwa pelabuhan yang berada di Sorong dan Banggai memiliki nilai Sa tertinggi, sedangkan pelabuhan di Banjarmasin memiliki nilai terkecil. Pelabuhan di Surabaya dan Tuban memiliki Sa yang hampir sama karena letak pelabuhan yang dekat, sedangkan Banyuwangi memiliki nilai Sa sedikit di atas keduanya. Pelabuhan di Padang, Lampung, dan Penajam harus menggunakan analisis respons situs-spesifik untuk menentukan respons spektrum desain, yang tidak dibahas dalam makalah ini. Perbandingan dengan SNI 2012 menunjukkan bahwa respons spektrum SNI 2019 memiliki Sa yang lebih tinggi dari pada SNI 2012. Namun, di beberapa daerah seperti Tuban dan Sorong, Sa SNI 2012 pada periode 0,1 - 0,6 detik bernilai lebih besar dari SNI 2019.
\end{abstract}

Kata kunci : respons spektrum, SNI 1726:2019, pelabuhan, Indonesia.

\section{INTRODUCTION}

The study of earthquake hazards continues to improve onward the progress of science and technology. This constant development often has an impact on the seismic design code. As an earthquake-prone country, Indonesia has a new seismic provision 
called SNI 1726:2019 (BSN, 2019). This code revises the current Indonesian seismic design code SNI 1726:2012 (BSN, 2012). The SNI 1726:2019 was developed based on the 2017 Indonesian Earthquake Source and Hazard Maps (PUSKIM, 2017) and adopting the ASCE 7-16 (ASCE, 2017), with several adjustments adapting the conditions of Indonesia. The change in seismic load analysis has an impact on the structural design. One of the widely used methods used for dynamic seismic analysis is response spectra. It shows the absolute maxima of various response parameters of damped (or undamped) elastic oscillators (single degree of freedom systems) for a set of vibration periods under an earthquake ground motion (Sucuoğlu \& Akkar, 2014). Several studies have been carried out regarding changes to the previous design code (Setiawan \& Imran, 2019). This paper is intended to explain the step-by-step approach for calculating response spectrum design, according to SNI 1726:2019, at several ports. Furthermore, the manual calculation results will be compared with the 2019 RSA, an application from PUSGEN -PUSKIM PUPR, to verify the results. It is also compared with SNI 1726:2012 to see the difference in the spectral acceleration difference between the two-building code.

This research chooses port structure as a study object because of its vital role for archipelago countries such as Indonesia. Failure of the port structure caused by an earthquake can disrupt the economy of a region. This research was conducted in 10 ports spread over five main islands in Indonesia. Figure 1 shows the city where the structure is located. However, it needs to be understood that it does not indicate the port or terminal's name. The analysis conducted in this paper is based on verified secondary data provided.

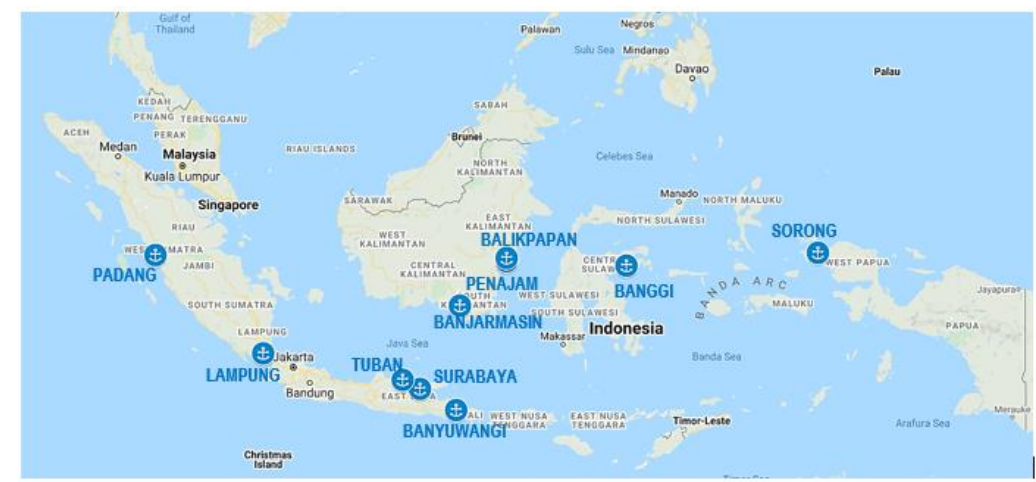

Figure 1 Location of the Ports

\section{METHODOLOGY}

\subsection{General}

Design response spectra calculation is conducted in several stages. Figure 2 shows the procedure for calculating response spectra, according to SNI 1726:2019, that 
developed based on ASCE 7-16. The first step in determining earthquake load in a structure is to conduct risk categorization.

\section{SEISMIC HAZARD REQUIREMENT}

* Provision from SNI 17262016

* Provision from ASCE 7 - 16

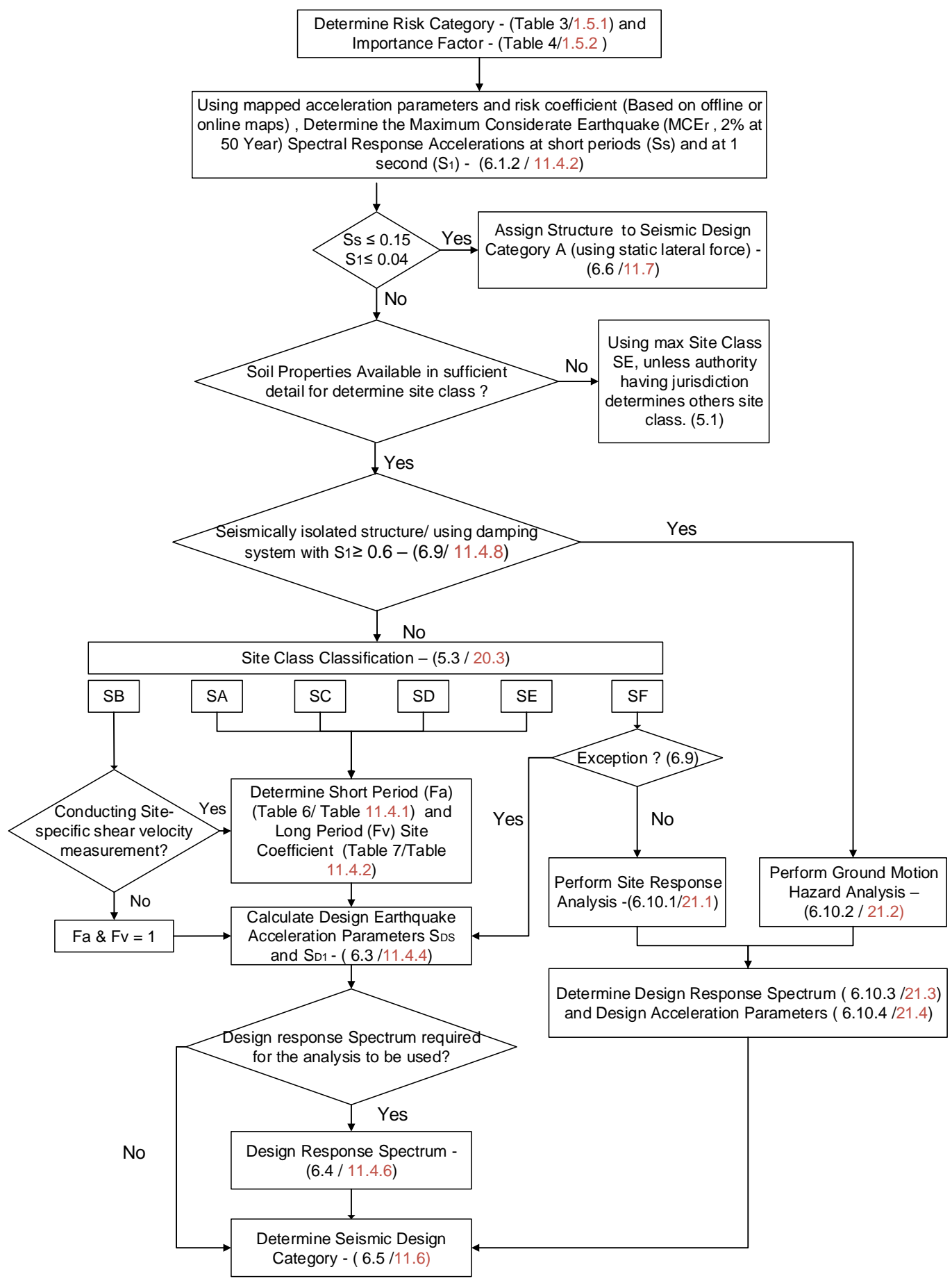

Figure 2 Response Spectra Development Procedure

Design Response Spectra Based on Earthquake Hazard Maps and Specific Soil Properties at Indonesian Ports

(Christino Boyke Surya Permana) 
Buildings and other facilities such as ports must be classified based on risks to human safety, life, and health-related consequences of structural failure or damage. The risk category for building and other structures in SNI 1726:2019 and ASCE 7-16 generally have the same criteria. The summary of these categories can be seen in Table 1 .

Table 1 Risk Category of Buildings and Other Structures

\begin{tabular}{lc}
\hline Use of Building and Structures & $\begin{array}{c}\text { Risk Category } \\
\text { (SNI 1726:2019 } \\
\text { /ASCE 7-16) }\end{array}$ \\
\hline $\begin{array}{l}\text { Buildings or other structures that have a low risk to human life if failure } \\
\text { happens }\end{array}$ & I \\
Buildings or other structures except those listed in different categories & II \\
$\begin{array}{l}\text { Buildings or other structures that have a substantial risk to human life if } \\
\text { failure happens }\end{array}$ & III \\
Buildings or other structures (not included in Risk Category IV) that \\
have the potentially significant economic impact or disruption to \\
everyday life if failure happens \\
$\begin{array}{l}\text { Buildings or other structures that have categorized as a vital object to the } \\
\text { community (essential facilities) }\end{array}$
\end{tabular}

For various risk categories of buildings and non-buildings in Table 1, the minimum design load for a structure shall incorporate the importance factors in SNI 1726:2019 Table 4 or ASCE 7-16 Table 1.5-2. The spectral response acceleration for short periods (Ss) and at 1 second period (S1) must be obtained from the Risk-Targeted Maximum Considered Earthquake (MCER) maps. Figures 3 and 4 show the RiskTargeted Maximum Considered Earthquake (MCER) for spectral response acceleration maps representing a 5\% damped acceleration and 1\% probability of collapse within 50 years period. These maps were adjusted for the soil site class between SB and SC, for short periods (0.2 seconds) and 1-second period according to the ASCE 7-16. It was developed based on hazard maps with a $2 \%$ probability of exceedance within 50 years (2,475-year earthquake periods) by the National Earthquake Study Center Team, published in the 2017 Indonesian Earthquake Source Hazard Maps. The study center team developed MCER maps with a grid interval of 0.10 and approximately 96,000 data for each spectral response acceleration. 


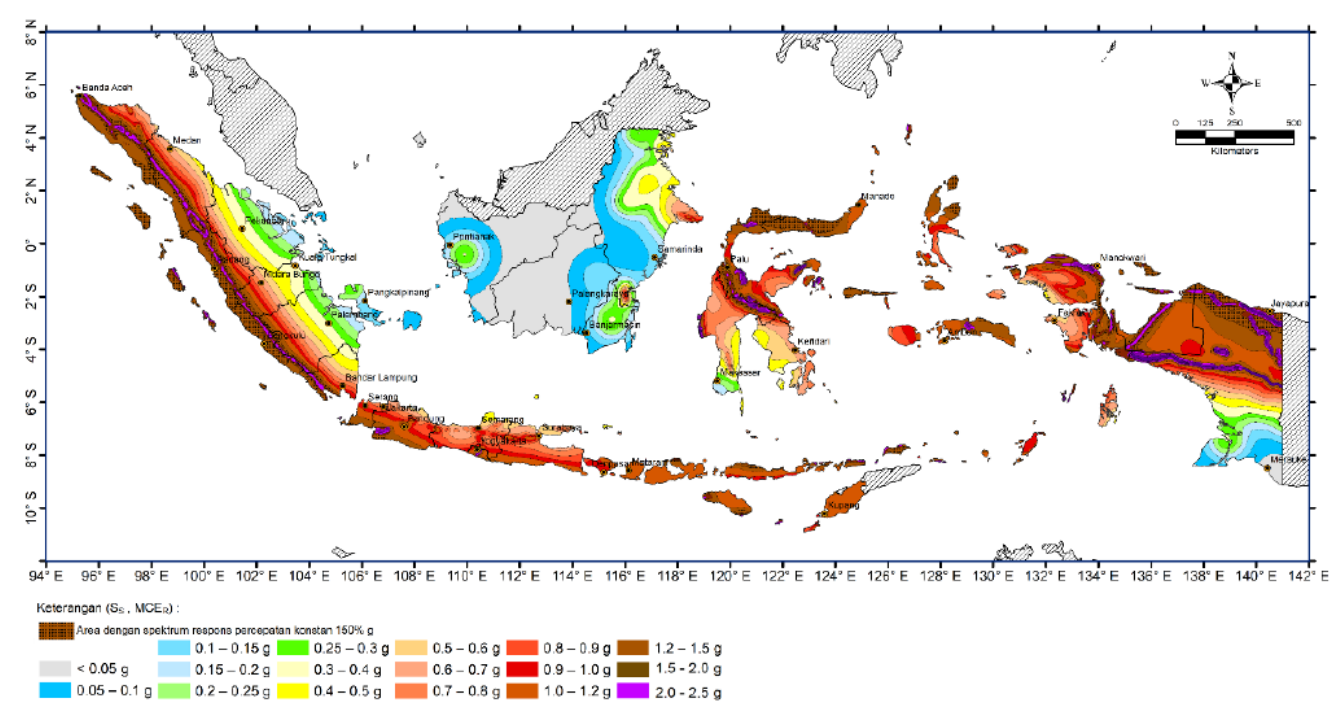

Figure 3 Ss Risk-Targeted Maximum Considered Earthquake $\left(\mathrm{MCE}_{\mathrm{R}}\right)$ Ground Motion Parameter for Indonesia for 0.2-s Spectral Response Acceleration (5\% of Critical Damping)

Source: PUSKIM, 2017

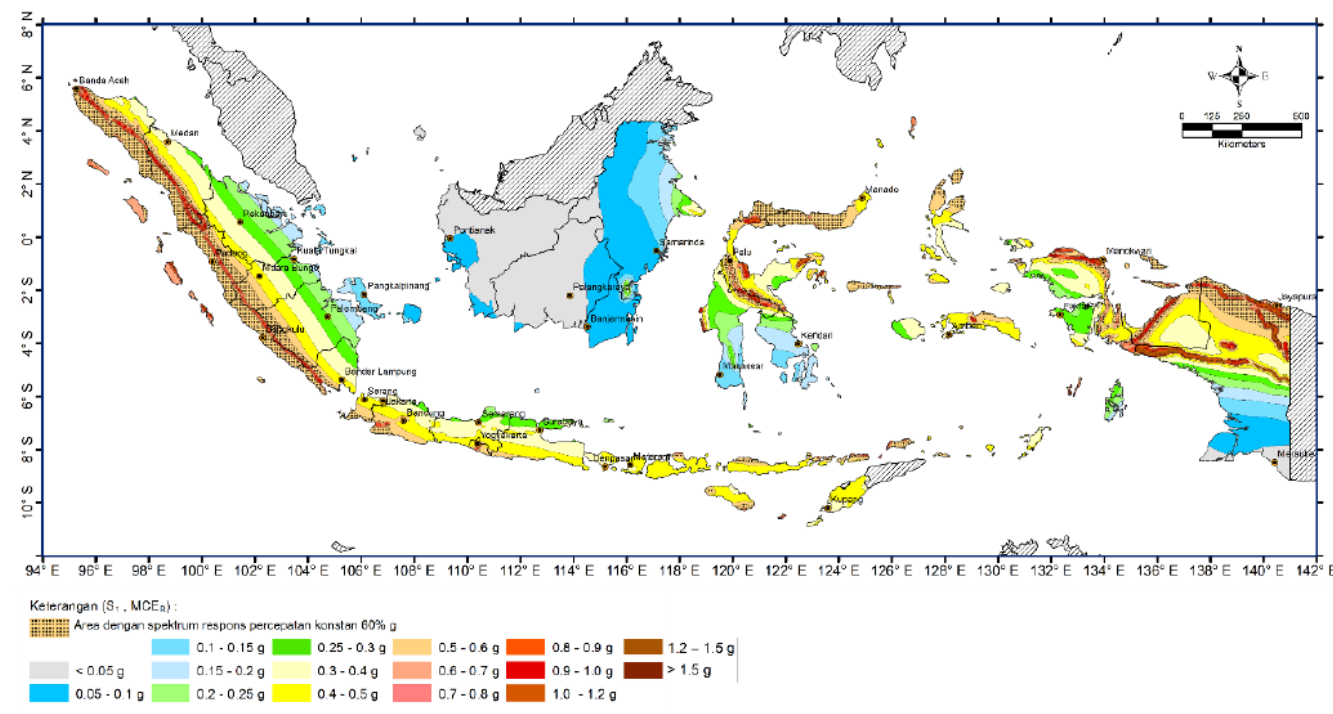

Figure $4 S_{1}$ Risk-Targeted Maximum Considered Earthquake $\left(\mathrm{MCE}_{\mathrm{R}}\right)$ Ground Motion Parameter for Indonesia for 1.0-s Spectral Response Acceleration (5\% of Critical Damping)

Source: PUSKIM, 2017

\subsection{Site Classification}

In the development of design response spectra for a structure in a specific site, the soil conditions must be classified first according to Table 2. Site soil classification is based on soil profile at $30 \mathrm{~m}$ upper layer. Suppose site-specific data is not available at a 
depth of $30 \mathrm{~m}$. In that case, soil properties can be estimated by professional geotechnical experts through a soil investigation report based on the site's geotechnical conditions.

Table 2 Site Classification

\begin{tabular}{|c|c|c|c|}
\hline Site Class & $\overline{V s}(\mathbf{m} / \mathbf{s})$ & $\bar{N}$ & $\begin{array}{c}\overline{\mathrm{Su}} \\
(\mathbf{K P a})\end{array}$ \\
\hline SA (Hard Rock) & $>1500$ & N/A & N/A \\
\hline SB (Rock) & $750-1500$ & N/A & N/A \\
\hline $\begin{array}{l}\text { SC (Very Dense Soil \& Soft } \\
\text { Rock) }\end{array}$ & $350-750$ & $>50$ & $\geq 100$ \\
\hline SD (Stiff Medium Soil) & $175-350$ & $15-50$ & $50-100$ \\
\hline \multirow[t]{2}{*}{ SE (Soft Clay Soil) } & $<175$ & $<15$ & $<50$ \\
\hline & \multicolumn{3}{|c|}{$\begin{array}{l}\text { Any site with more than } 3 \mathrm{~m} \text { of soil that has the following } \\
\text { characteristics: } \\
\begin{array}{l}\text { - Plasticity index } \mathrm{PI}>20, \\
\text { - } \quad \text { Moisture content } \mathrm{w} \geq 40 \%, \\
\text { - } \quad \text { Undrained shear strength } \overline{S u}<25 \mathrm{kPa}\end{array}\end{array}$} \\
\hline $\begin{array}{l}\text { SF (Special Soil, requiring } \\
\text { site response analysis and } \\
\text { special geotechnical site } \\
\text { investigation) }\end{array}$ & \multicolumn{3}{|c|}{$\begin{array}{l}\text { - For soils that have a high risk of potential failure or collapse } \\
\text { under seismic loadings. For example, liquefiable soils, quick } \\
\text { and highly sensitive clays, and collapsible weakly cemented } \\
\text { soils. } \\
\text { - Peats and highly organic clays with the thickness of soil }(\mathrm{H}> \\
3 \mathrm{~m}) \\
\text { - Very high plasticity clays }(\mathrm{H}>7.5 \mathrm{~m}) \text { with PI }>75 \\
\text { - Very thick, soft/medium stiff clays }(\mathrm{H}>35 \mathrm{~m}) \text { with } \overline{\mathrm{Su}}<50 \\
\mathrm{kPa})\end{array}$} \\
\hline
\end{tabular}

Source: BSN, 2019

Determination of site classification using Table 2 requires soil properties data with sufficient detail. When the data is not available, Site Class SE shall be used as a basis for further calculations. Assignment to Site Class A and B should not be made if more than $3 \mathrm{~m}$ of soil layer between the rock surface and the bottom of the footing or mat foundation. Assignments for Site Classes C, D, and E are based on at least two of the following three methods:

1. Using the $\overline{V S}$ Method for the top $30 \mathrm{~m}$ of a soil layer

2. Using the $\bar{N}$ Method for the top $30 \mathrm{~m}$ of a soil layer

3. Using the $\overline{N c h}$ Method for the top $30 \mathrm{~m}$ of cohesionless soil layers $(\mathrm{PI}<20)$ or using the $\overline{S u}$ Method for the top $30 \mathrm{~m}$ of cohesive soil layers (PI > 20).

If there are soil parameters that are not available under certain conditions, correlation can be made with other known soil parameters. For example, undrained shear strength $\left(S_{u}\right)$ can be obtained through correlation with the number of the blow from Standard Penetration Test (N-SPT), liquid limit (LL), plasticity index (PI), and natural 
water content $\left(\mathrm{w}_{\mathrm{n}}\right)$. Table 3 shows some equations that can be used to estimate the value of $S_{u}$.

Table 3 Correlation Between Su and N-SPT

\begin{tabular}{llc}
\hline \multicolumn{1}{c}{ Researchers } & \multicolumn{1}{c}{ Explanation } & Su (kPa) \\
\hline (Sanglerat, 1972) & Silty Clay & $10 \mathrm{~N}$ \\
(Terzaghi et al., 1996) & Fine-grained soil & $6.25 \mathrm{~N}$ \\
(Décourt, 1990) & Clay & $12.5 \mathrm{~N}$ \\
(Sivrikaya \& Toğrol, 2002) & Low Plastic Soil & $3.35 \mathrm{~N}$ \\
(Sivrikaya, 2009) & UU Test & $\mathrm{Su}=3.33 \mathrm{~N}-0.75 \mathrm{wn}+0.20 \mathrm{LL}+1.67 \mathrm{PI}$ \\
\hline
\end{tabular}

As to estimate the value of $\mathrm{V}_{\mathrm{S}}$ when seismic testing is not carried out in the area, the guidelines from Pacific Earthquake Engineering Research Center (PEER 2012/08) (Wair et al., 2012) provides recommendations for Vs - N SPT correlation equations as listed in Table 4. These correlation equations are prepared for all soils, clays and silts, sands, and gravels. The studies presented a correlation between $\mathrm{V}_{\mathrm{S}}$ and soil parameters like N-SPT and effective stress $\left(\sigma^{\prime} v\right)$. Field N-values must be corrected because of the standard testing procedure variations and then normalized to the reference energy ratio of $60 \%\left(\mathrm{~N}_{60}\right)$.

Table 4 Recommended $V_{\text {s. }}$ - Effective Stress and N-SPT Correlation Equation

\begin{tabular}{ll}
\hline Soil Type & Shear Wave Velocity $(\mathbf{V s}) \mathbf{~ m} / \mathbf{s}$ \\
\hline All Soil & $30 \mathrm{~N}_{60}^{0.215} \sigma^{\prime} \mathbf{v}^{0.275}$ \\
Clays \& Silts & $26 \mathrm{~N}_{60}^{0.17} \sigma^{\prime} \mathrm{v}^{0.32}$ \\
Sands & $30 \mathrm{~N}_{60}^{0.23} \sigma^{\prime} \mathrm{v}^{0.23}$ \\
Gravels & $53 \mathrm{~N}_{60}^{0.19} \sigma^{\prime} \mathrm{v}^{0.18}$ \\
\hline${ }^{*}\left(\sigma^{\prime} \mathrm{v}\right)$ in $\mathrm{kPa}$ &
\end{tabular}

Source: Wair et al., 2012

\subsection{Site Coefficient $F_{a}$ and $F_{v}$}

The determination of MCER spectral response acceleration parameters on a ground surface requires a seismic amplification factor (also known as site coefficient). As described in Table 5 and Table 6, this amplification factor comprises the amplification factor of vibrations in a short period $(\mathrm{Fa})$ and 1 second period $(\mathrm{Fv})$. Fa and Fv used in SNI 1726:2019 were adopting the recommendation from the Pacific Earthquake Engineering Research Center (PEER 2013/13) that is listed in research conducted by Jonathan P Steward et al. (Stewart \& Seyhan, 2013). Therefore, there are coefficient values that are slightly different from those defined in ASCE 7-16. 
Table 5 Short-Period Site Coefficient, $F_{a}$

\begin{tabular}{|c|c|c|c|c|c|c|}
\hline \multirow[t]{2}{*}{ Site Class } & \multicolumn{6}{|c|}{$\begin{array}{l}\text { Mapped Risk-Targeted Maximum Considered Earthquake (MCER) Spectral } \\
\text { Response Acceleration Parameter at Short Period, } T=0,2 \mathrm{~s}, S_{s}\end{array}$} \\
\hline & $S_{s} \leq 0.25$ & $S_{s}=0.5$ & $S_{s}=0.75$ & $S_{s}=1.0$ & $S_{s}=1.25$ & $S_{s} \geq 1.5$ \\
\hline SA & 0.8 & 0.8 & 0.8 & 0.8 & 0.8 & 0.8 \\
\hline SB & 0.9 & 0.9 & 0.9 & 0.9 & 0.9 & 0.9 \\
\hline $\mathrm{SC}$ & 1.3 & 1.3 & 1.2 & 1.2 & 1.2 & 1.2 \\
\hline SD & 1,6 & 1,4 & 1,2 & 1,1 & 1,0 & 1,0 \\
\hline SE & 2,4 & 1,7 & 1,3 & 1,1 & 0,9 & 0,8 \\
\hline SF & \multicolumn{6}{|c|}{ Site-Specific Response Analysis } \\
\hline
\end{tabular}

Source: BSN, 2019

Table 6 Long-Period Site Coefficient, $\mathrm{F}_{\mathrm{v}}$

\begin{tabular}{ccccccc}
\hline Site Class & \multicolumn{6}{c}{$\begin{array}{c}\text { Mapped Risk-Targeted Maximum Considered Earthquake (MCER) Spectral } \\
\text { Response Acceleration Parameter at Short Period, } \mathbf{T = 1} \mathbf{~ s , ~} \boldsymbol{S}_{\boldsymbol{I}}\end{array}$} \\
\cline { 2 - 6 } & $\boldsymbol{S}_{\boldsymbol{I}} \leq \mathbf{0 . 1}$ & $\boldsymbol{S}_{\boldsymbol{I}}=\mathbf{0 . 2}$ & $\boldsymbol{S}_{\boldsymbol{I}}=\mathbf{0 . 3}$ & $\boldsymbol{S}_{\boldsymbol{I}}=\mathbf{0 . 4}$ & $\boldsymbol{S}_{\boldsymbol{I}}=\mathbf{0 . 5}$ & $\boldsymbol{S}_{\boldsymbol{I}} \geq \mathbf{0 . 6}$ \\
\hline SA & 0.8 & 0.8 & 0.8 & 0.8 & 0.8 & 0.8 \\
SB & 0.8 & 0.8 & 0.8 & 0.8 & 0.8 & 0.8 \\
SC & 1.5 & 1.5 & 1.5 & 1.5 & 1.5 & 1.4 \\
SD & 2.4 & 2.2 & 2.0 & 1.9 & 1.8 & 1.7 \\
SE & 4.2 & 3.3 & 2.8 & 2.4 & 2.2 & 2.0 \\
SF & \multicolumn{5}{c}{ Site-Specific Response Analysis } \\
\hline
\end{tabular}

Source: BSN, 2019

\subsection{Design Response Spectra}

The Risk-Targeted Maximum Considered Earthquake $\left(\mathrm{MCE}_{\mathrm{R}}\right)$ spectral response acceleration parameters for short periods $\left(\mathrm{S}_{\mathrm{MS}}\right)$ and 1 second $\left(\mathrm{S}_{\mathrm{M} 1}\right)$ that already adjusted for site class effects (represented by site coefficient) shall be determined by Equation (1) and (2), respectively.

$$
\begin{aligned}
& S_{M S}=F_{a} \cdot S_{S} \\
& S_{M I}=F_{v} . S_{I}
\end{aligned}
$$

Where:

$\mathrm{S}_{\mathrm{S}}=$ the mapped MCER spectral response acceleration parameter at short periods, determined following Figure 3.

$\mathrm{S}_{1}=$ the mapped MCER spectral response acceleration parameter at 1 second period, determined following Figure 4.

Design earthquake spectral response acceleration parameters for short periods $\left(\mathrm{S}_{\mathrm{DS}}\right)$ and 1 second periods $\left(\mathrm{S}_{\mathrm{D} 1}\right)$ shall be determined from Equation (3) and (4), respectively.

$$
\begin{aligned}
& S_{D S}=2 / 3 . S_{M S} \\
& S_{D I}=2 / 3 . S_{M I}
\end{aligned}
$$

The last step of this method is to develop a response spectrum curve, which is a graph of the relationship between spectral response acceleration (Sa) and Periods (T). 
Response spectrum curves are performed according to this method if site-specific response spectrum and ground motion procedures are not used. The response spectrum curve development is based on the following conditions:

a. The design spectral response acceleration ( $\mathrm{Sa}$ ) must be calculated as Equation (5) if periods $\mathrm{T}<\mathrm{T}_{0}$.

$$
S a=S_{D S}\left(0,4+0,6 \frac{T}{T_{O}}\right)
$$

b. The design spectral response acceleration (Sa) must be calculated as equal to $S_{\mathrm{DS}}$ if, $\mathrm{T}_{\mathrm{s}} \geq \mathrm{T} \geq \mathrm{T}_{\mathrm{o}}$

c. The design spectral response acceleration (Sa) must be calculated as Equation (6) if periods $\mathrm{T}_{\mathrm{s}} \leq \mathrm{T} \leq \mathrm{T}_{\mathrm{L}}$

$$
S_{a}=S_{D 1} / T \text {. }
$$

d. The design spectral response acceleration (Sa) must be calculated as Equation (7) if periods $\mathrm{T}>\mathrm{T}_{\mathrm{L}}$

$$
S_{a}=\frac{S_{D 1} \cdot T_{L}}{T^{2}}
$$

Where:

$\mathrm{S}_{\mathrm{D} 1} \quad=$ the design spectral response acceleration parameter at a 1 second period

$\mathrm{S}_{\mathrm{DS}} \quad=$ the design spectral response acceleration parameter at short periods

$\mathrm{T}=$ the fundamental period of the structure $(\mathrm{s})$

$\mathrm{T}_{0} \quad=0.2\left(\mathrm{~S}_{\mathrm{D} 1} / \mathrm{S}_{\mathrm{DS}}\right)$

$\mathrm{T}_{\mathrm{S}} \quad=\mathrm{S}_{\mathrm{D} 1} / \mathrm{S}_{\mathrm{DS}}$, and

$\mathrm{TL}=$ long-period transition periods shown in Figure 5

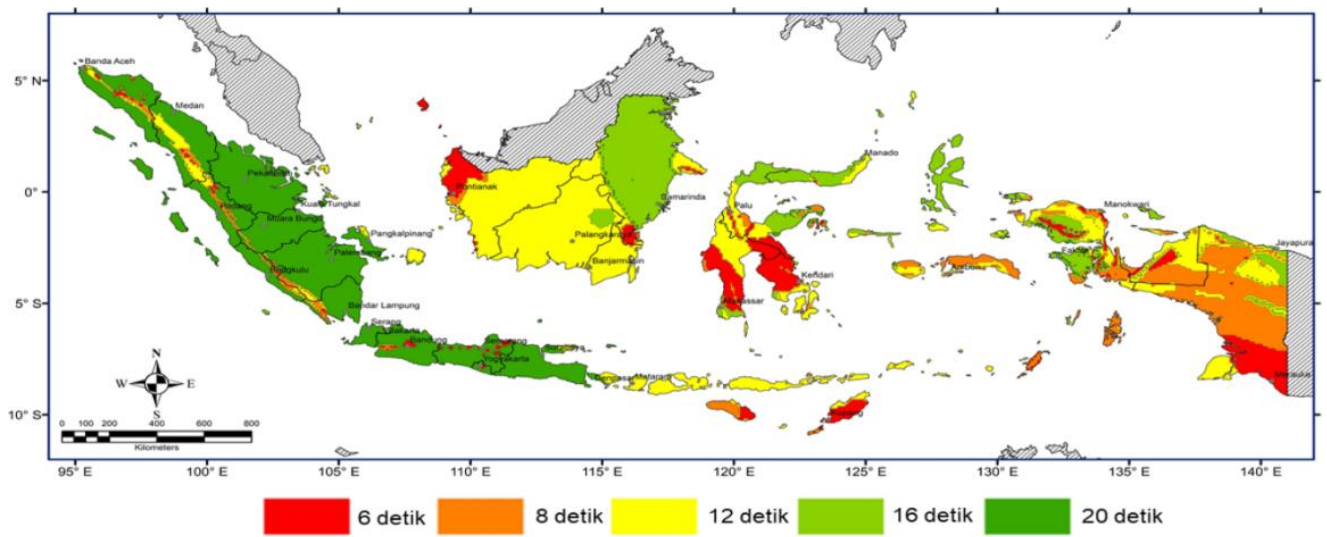

Figure 5 Long-Period Transition Periods Map

Source: BSN, 2019

Design Response Spectra Based on Earthquake Hazard Maps and Specific Soil Properties at Indonesian Ports 


\section{CALCULATION OF DESIGN RESPONSE SPECTRA}

The first step to analyzing the design response spectra is to determine the risk category of the structure. Based on Table 1, the port structure falls within the risk category III. It is because the port structure has the potential to induce a substantial economic impact or disruption to everyday life if failure happens. Afterward, the site classification process is carried out based on the port location's specific soil properties. Soil properties data from the results of field and laboratory tests are required to carry out this process. However, complete data is not always available in several locations. Consequently, some correlation needs to be carried out to determine the necessary parameters.

Table 7 presents the results of site classification at ten ports in Indonesia. The table shows that the site class SD (rigid medium soil) and SF (Special Soil) dominate. Some ports, such as Surabaya, Banyuwangi, and Tuban, are classified as SD because they have an $\bar{N}$ value of 28,15 , and 28 , respectively. Moreover, the code is also classified $\overline{S u}$ and $\overline{V S}$ values of these locations as the SD site. Port locations in Padang, Lampung, and Penajam fall within the SF category because there are very thick soft/medium stiff clays with a thickness of more than $35 \mathrm{~m}$ with $\overline{S u}<50 \mathrm{kPa}$ at these locations. $\bar{N}$ and $\overline{V s}$ value in Banjarmasin and Balikpapan area below 15 and $175 \mathrm{~m} / \mathrm{s}$, respectively. Therefore, we have classified these locations as site class SE. Whereas Banggai, which is dominated by cohesionless soils, is included in the site class SC because it has $\bar{N}$ values above 50 and $\overline{V s}$ above $350 \mathrm{~m} / \mathrm{s}$.

Table 7 Site Classification of 10 Ports in Indonesia

\begin{tabular}{|c|c|c|c|c|c|c|c|c|}
\hline \multirow[b]{2}{*}{ Port Location } & \multicolumn{7}{|c|}{ Soil Parameters } & \multirow[b]{2}{*}{$\begin{array}{c}\text { Site } \\
\text { Classification }\end{array}$} \\
\hline & $\begin{array}{c}\overline{v_{s}} \\
(\mathrm{~m} / \mathrm{s})\end{array}$ & $\bar{N}$ & $\begin{array}{c}\overline{S_{u}} \\
(\mathrm{Kpa})\end{array}$ & $\mathrm{Pl}$ & wn (\%) & $\begin{array}{l}\text { Very thick } \\
\text { soft/medium stiff } \\
\text { clays }(\mathrm{H}>35 \mathrm{~m}) \\
\text { with } \overline{S_{u}}<50 \\
\mathrm{kPa})\end{array}$ & $\begin{array}{l}\text { Peats and highly } \\
\text { organic clays with } \\
\text { the thickness of } \\
\text { soil }(\mathrm{H}>3 \mathrm{~m})\end{array}$ & \\
\hline 1 Surabaya & 243 & 28 & 86 & 38.35 & 39.536 & No & No & SD \\
\hline 2 Tuban & 222 & 15 & 66 & 33.19 & 29.215 & No & No & SD \\
\hline 3 Banyuwangi & 248 & 28 & 58 & 0 & 37.61 & No & No & SD \\
\hline 4 Padang & 171 & 3 & 37 & 53.44 & 87.7 & Yes & No & SF \\
\hline 5 Lampung & 125 & 3 & 21 & $\mathrm{~N} / \mathrm{A}$ & $\mathrm{N} / \mathrm{A}$ & Yes & No & SF \\
\hline 6 Banjarmasin & 163 & 2 & 33 & 45.20 & 80.74 & No & No & SE \\
\hline 7 Balikpapan & 149 & 2 & 49 & 44.28 & 51 & No & No & SE \\
\hline 8 Penajam & 181 & 5 & 47 & 43.20 & 55 & Yes & No & SF \\
\hline 9 Banggai & 354 & 57 & 139 & 62.88 & 51.64 & No & No & SC \\
\hline 10 Sorong & 273 & 36 & 45 & $\mathrm{~N} / \mathrm{A}$ & $\mathrm{N} / \mathrm{A}$ & No & No & SD \\
\hline
\end{tabular}


The next step of analysis is to obtain the mapped $\mathrm{MCE}_{\mathrm{R}}$ spectral response acceleration parameters at short and 1 second periods $\left(S_{s}\right.$ and $\left.S_{1}\right)$ as determined following Figure 3 and Figure 4. Then by multiplying these parameters with site coefficient factors (Table 5 and Table 6), we can obtain an $\mathrm{MCE}_{\mathrm{R}}$ spectral response acceleration parameter for short periods $\left(\mathrm{S}_{\mathrm{MS}}\right)$ and at 1 second $\left(\mathrm{S}_{\mathrm{M} 1}\right)$. By utilizing these values, we can determine the design earthquake spectral response acceleration parameters at short periods $\left(\mathrm{S}_{\mathrm{DS}}\right)$ and 1-s periods $\left(S_{\mathrm{D} 1}\right)$, as shown in Table 8. A further review needs to be performed at Padang, Lampung, and Penajam as they are site class SF locations. $F_{a}$ and $F_{v}$ values at this location were selected based on Site Class $E$, and the $S_{\mathrm{DS}}$ and $\mathrm{S}_{\mathrm{D} 1}$ values obtained must be compared with the upper bound values for Seismic Design Category B of 0.33 and 0.133 , respectively. Table 8 shows that the $S_{D S}$ and $S_{D 1}$ values of the three cities are above the required limits. Therefore, a specific site response analysis must be used to determine the design response spectra. It means that the calculation of these three locations' design response spectra cannot use the procedure described in this study.

Table 8 Design Earthquake Spectral Response Acceleration Parameters

\begin{tabular}{|c|c|c|c|c|c|c|c|c|c|}
\hline & Port Location & SS & S1 & $\mathbf{F a}$ & $\mathbf{F v}$ & SMS & SM1 & SDS & SD1 \\
\hline 1 & Surabaya & 0,65 & 0,27 & 1,28 & 2,06 & 0,84 & 0,560 & 0,560 & 0,380 \\
\hline 2 & Tuban & 0,6 & 0,28 & 1,28 & 2,06 & 0,77 & 0,580 & 0,520 & 0,390 \\
\hline 3 & Banyuwangi & 0,888 & 0,37 & 1,18 & 2 & 1,05 & 0,740 & 0,700 & 0,500 \\
\hline 4 & Padang* & 1,54 & 0,62 & 0,8 & 2 & 1,24 & 1,24 & 0,830 & 0,830 \\
\hline 5 & Lampung* & 0,9 & 0,45 & 1,18 & 2,3 & 1,07 & 1,040 & 0,720 & 0,700 \\
\hline 6 & Banjarmasin & 0,088 & 0,045 & 2,4 & 4,2 & 0,22 & 0,190 & 0,150 & 0,130 \\
\hline 7 & Balikpapan & 0,11 & 0,083 & 2,4 & 4,2 & 0,27 & 0,350 & 0,180 & 0,240 \\
\hline 8 & Penajam* & 0,12 & 0,08 & 2,32 & 4,2 & 0,28 & 0,340 & 0,190 & 0,230 \\
\hline 9 & Banggai & 0,95 & 0,4 & 1,2 & 1,5 & 1,14 & 0,600 & 0,760 & 0,400 \\
\hline 10 & Sorong & 1,34 & 0,53 & 1 & 1,7 & 1,34 & 0,910 & 0,900 & 0,610 \\
\hline
\end{tabular}

* Must be using site response analysis.

A response spectrum curve can be developed using the stipulation in equations 5 to 7 , as shown in Figure 6 and Figure 7. The results of the response spectrum curves are then verified with the results from the software. The software used is the RSA2019, which the National Center of Earthquake Studies developed. This software can produce a response curve in all regions of Indonesia accurately. 


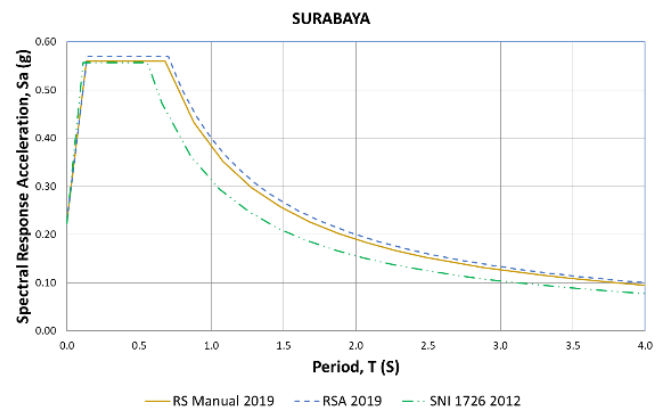

(a)

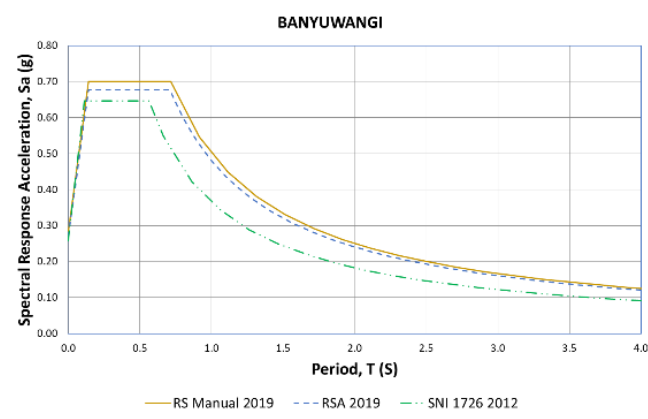

(c)

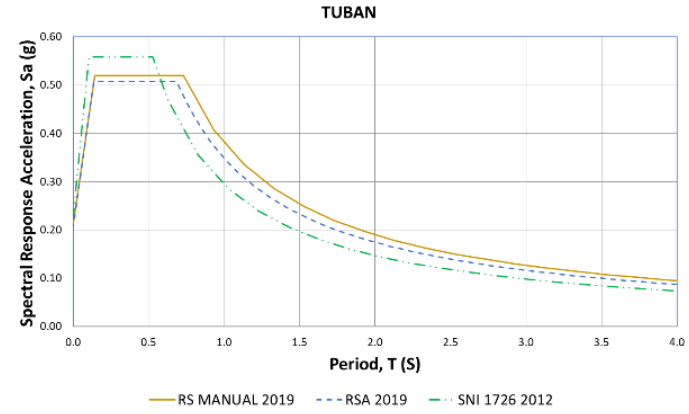

(b)

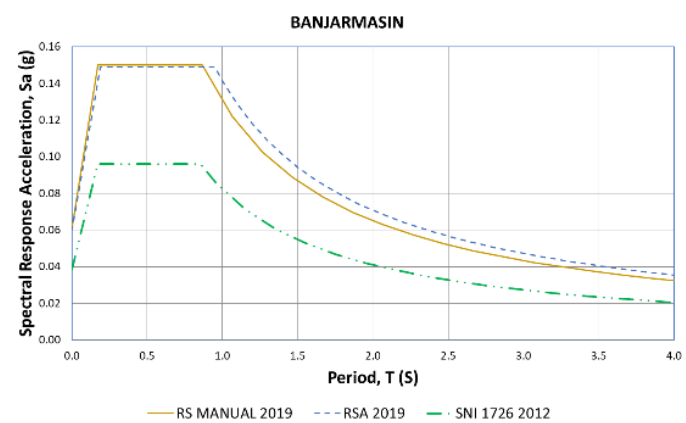

(d)

Figure 6 Design Response Spectra Curve for (a) Surabaya, (b) Tuban, (c) Banyuwangi, (d) Banjarmasin

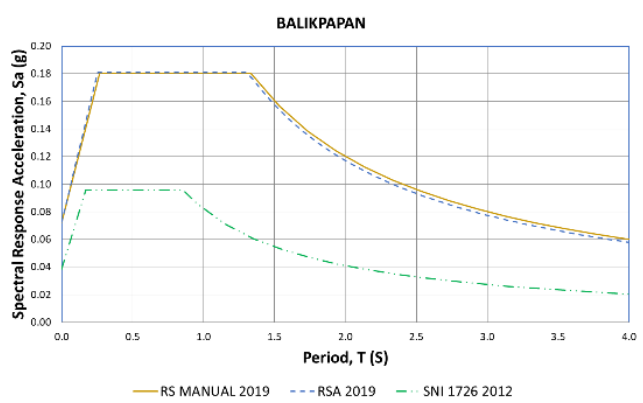

(e)

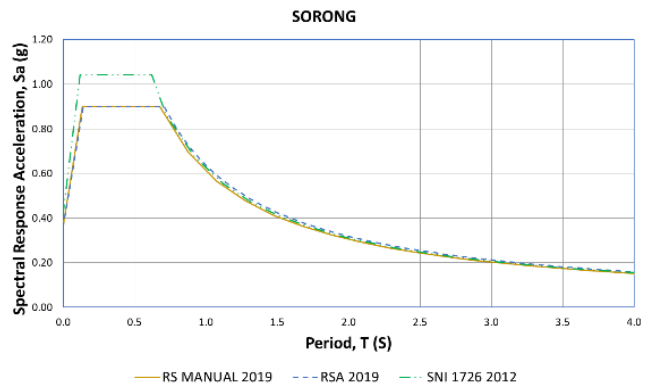

(g)

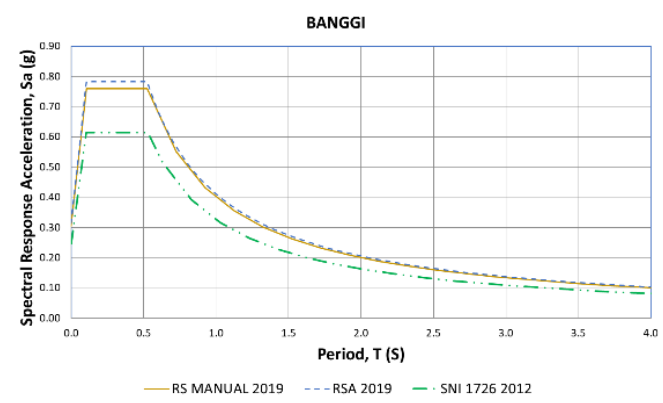

(f)

Figure 7 Design Response Spectra Curve for (e) Balikpapan, (f) Banggai, (g) Sorong 
The comparison of curves in Figure 6 shows that the results of manual calculations with procedures per SNI 1726:2019 produce identical results to the results of the RSA 2019 software. Nevertheless, there is a slight difference in several locations due to the lack of accuracy in manually determining Ss and S1. The comparison with SNI 1726:2012 shows that the response spectra of SNI 1726:2019 have a higher Sa than SNI 1726:2012. However, in some areas such as Tuban and Sorong, the Sa of SNI1726:2012 at 0.1 to 0.6 s period are more significant than SNI 1726:2019. This difference does not significantly affect the wharf structure because the jetty's natural period is in the range of 0.5 to $2 \mathrm{~s}$. For Surabaya and Banyuwangi, Sa's difference is slight, around $0.05 \mathrm{~g}$ on average, so it gave a negligible impact on wharf design. At Balikpapan and Banjarmasin, the increase in SA value under the new code is significant, between 50 and $80 \%$. These increases led to the necessity to evaluate buildings' strength for a structure that has been established and designed with old regulations.

\section{CONCLUSION}

Based on the result presented in this paper, it can be concluded that:

a. The results of manual calculations with procedures per SNI 1720:2019 already verified with RSA2019.

b. The ports located in Sorong and Banggai have the highest $S_{a}$ values than other locations, while the port in Banjarmasin has the smallest value of $S_{a}$. Surabaya and Tuban have nearly the same $S_{a}$ value due to the port's close location. In contrast, Banyuwangi has a $S_{a}$ value slightly above them even though it is in an adjacent area.

c. The comparison with SNI 1726:2012 shows that the response spectra of SNI 1726:2019 have a higher Sa than SNI 1726:2012. However, in some areas such as Tuban and Sorong, the Sa of SNI1726:2012 at 0.1 to 0.6 s period are more extensive than SNI 1726:2019.

d. At Balikpapan and Banjarmasin, the increase in SA value under the new code is significant, between 50 and $80 \%$. These increases led to the necessity to evaluate buildings' strength for a structure that has been established and designed with old regulations.

e. The ports located in Padang, Lampung, and Penajam must use a specific site response analysis method to determine the design response spectra. 


\section{REFERENCES}

1. ASCE. (2017). Minimum Design Loads and Associated Criteria for Buildings and Other Structures. American Society of Civil Engineers. https://doi.org/10.1061/9780784414248

2. BSN. (2012). SNI 1726:2012 Tata Cara Perencanaan Ketahanan Gempa Untuk Bangunan Gedung.

3. BSN. (2019). SNI 1726:2019 Tata Cara Perencanaan Ketahanan Gempa Untuk Struktur Bangunan Gedung Dan Non Gedung.

4. Décourt, L. (1990). The Standard Penetration Test: State-of-the-Art-Report (No. 179). Norwegian Geotechnical Institute Publication.

5. PUSKIM. (2017). Peta Sumber dan Bahaya Gempa Indonesia Tahun 2017.

6. Sanglerat, G. (1972). The Penetrometer and Soil Exploration: Interpretation of Penetration Diagrams - Theory and Practice. Elsevier Publishing Co.

7. Setiawan, J., \& Imran, I. (2019). Evaluasi Geser Dasar Minimun pada SNI 17262012. Jurnal Teknik Sipil, 10(2), 166-184. https://doi.org/10.28932/jts.v10i2.1390

8. Sivrikaya, O. (2009). Comparison of Artificial Neural Networks Models with Correlative Works on Undrained Shear Strength. Eurasian Soil Science, 42(13), 1487-1496. https://doi.org/10.1134/S1064229309130092

9. Sivrikaya, O., \& Toğrol, E. (2002). Relations Between SPT-N and qu. 5th Intern. Congress on Advances Civil Engineering, 943-952.

10. Stewart, J. P., \& Seyhan, E. (2013). Semi-Empirical Nonlinear Site Amplification and Its Application in NEHRP Site Factors. Berkeley, United States of America: Pacific Earthquake Engineering Research Center, November.

11. Sucuoğlu, H., \& Akkar, S. (2014). Basic Earthquake Engineering. In Basic Earthquake Engineering. Springer International Publishing. https://doi.org/10.1007/978-3-319-01026-7

12. Terzaghi, K., Peck, R., \& Mesri, G. (1996). Soil Mechanics in Engineering Practice. John Wiley and Sons Inc.

13. Wair, B. R., Dejong, J. T., \& Shantz, T. (2012). Guidelines for Estimation of Shear Wave Velocity Profiles. Pacific Earthquake Engineering, 8 (December), 68. 